\title{
Standing Patellar Desmotomy and its Outcome in Cows
}

\author{
E. Kalaiselvan ${ }^{1} *$ and D. Desinguraja ${ }^{2}$ \\ ${ }^{1}$ Division of Surgery, ICAR-Indian Veterinary Research Institute, Izatnagar, \\ Bareilly, Uttar Pradesh, India \\ ${ }^{2}$ Veterinary Dispensary-Aragalur, Thalaivasal block, Salem-Tamilnadu, India \\ *Corresponding author
}

\section{A B S T R A C T}

\section{Keywords}

Standing patellar desmotomy, Cross bred, Prevalence, Thalaivasal block

\section{Article Info}

Accepted:

22 June 2020

Available Online:

10 July 2020
Patellar desmotomy is a successful surgical procedure for stringhalt in cattle. In this paper describes about prevalence of upward fixation of patella respective of breed, age, status of the animal and level of mineral inclusion in Thalaivasal block of Salem, Tamilnadu. Also surgical procedure, outcome of standing patellar desmotomy and response of veterinarian particular about this condition were studied. Besides it achieves good outcome of patient with minimal restraining and it would be beneficial for the field veterinarians and farmers about the condition.

\section{Introduction}

Upward fixation of patella is one of the surgical condition which is mostly neglected by veterinarians, due to need of skilled surgical personnel. Upward fixation of patella also known as stringhalt/dharuk (hindi)/sundu vadham (tamil) in cattle. This is most commonly noticed in cattle and buffaloes. The causes are (multifactorial) Hereditary, nutritional deficiency, over exploitation, breed, external traumas, intense contraction of the crural triceps muscle and morphological changes in stifle joint (Chandrapuria et al., 2012 and Singh et al., 2015). Because of the limitation of patellar movement, the clinical signs shows that inability to flex the hind limb and dragging of toe while sudden progression of animal (Greenough, 2015). But after few steps it may disappear as patella glides normally over the trochlear ridge. But when bilateral upward fixation of patella restricts the animal activity more, which is very unsightly for viewer. Medial patellar desmotomy is considered as gold standard of therapy. There are various form of conducting procedure standing, lateral recumbency with BP blade or silk (Naveen et al., 2013 and Sherif, 2017) In this research study we discuss about the outcome of standing patellar 
desmotomy procedure and prevalence of condition in (Thalaivasal block) in fifteen cases.

\section{Materials and Methods}

The study was conducted in Thalaivasal block, Salem district of Tamilnadu over a period of 3 months. Clinically diagnosis was made based on the signs of hesitation of stride, dragging of the toe on the ground and subsequent hyper flexion of stifle (Hanson and Peyton, 1987). On call basis cases attended, medically history, course of ailments (in months), breed, sex, age (in years which completed) and status of animal (lactating/non-lactating/trimester of pregnancy), response of previous veterinarian (Postponed/No-response) and level mineral supplementation ( $50 \mathrm{~g}$ per cattle considered as optimal, below $50 \mathrm{~g}$ considered as suboptimal) of about the problem were recorded. Surgically standing patellar desmotomy carried followed by surgical parameters clinically severance of ligament (\%), surgical site Swelling, Bleeding, Outcome after surgery (100\% normal activity considered as good and if below its considered as bad) and any other complications were recorded and analysed with average and percentage of basic statistics.

\section{Surgical procedure}

Preemptively $5 \mathrm{~g}$ of streptomycin-penicillin antibiotic and $15 \mathrm{ml}$ of meloxicam administered intramuscularly. All the animals made stand on either tree or pole or Travis. The tails switch restraining done by one person from the back of the animal. Inner aspect of the thigh in which where medial line of flap of the flank attaches with limb prepared aseptically for surgery. The medial patellar ligament identified with digital guidance and over and beneath that $5 \mathrm{ml}$ of $2 \%$ lignocaine infiltrated. After 5 minutes of local analgesic infiltration, with left index finger guidance, right hand with No. 21 Bard parker blade inserted into the dipression between middle and medial patellar ligament. Then the blade turned towards medial side like horizontal transection of ligament. Complete severance of the ligament confirmed by the palpable depression. After that $5 \mathrm{ml}$ Tincture iodine infused into the wound cavity. Animal trotted fast and examined for gait and activity.

\section{Results and Discussion}

In this study all animals were crossbred cows. The medical and surgical parameters represented in the table 1 and 2 respectively taken into the consideration for results and discussion. The condition more prevalent in cross bred jersey cow than cross bred HF. As the Thalaivasal block mostly plain hot and humid area (SDDM, 2018 and DSR, 2018). Hence the breed of choice here mostly jersey and sex wise all the animals are female due to economic reason in rural areas. Average age of occurrence of stringhalt in cattle is 5 years as reported in other studies (Singh et al., 2015). Duration of illness is on an average 5.6 months. Response of veterinarian about the therapy is about $46.66 \%$ postponed and $40 \%$ unattended. This duration of illness and on call response of veterinarian merely evidenced that lack of skill regarding patellar desmotomy procedure. Prevalence of upward fixation of patella is $46 \%$ in Lactating, $40 \%$ in last trimester of pregnancy and $13.33 \%$ in non-lactating cows. Also it was found that $86.66 \%$ in sub-optimal mineral supplemented animals.

In comparison of status of animal and level of mineral supplementation giving an inference that during high mineral needs and suboptimal level of mineral inclusion may be potential cause for upward fixation of patella. This result has similarities with other studies 
(Silva et al., 2004 and Dhillon et al., 2009). Although many causes intrinsic factors reported, this may be one of the common cause in Thalaivasal block as reported in other studies. In this study all animals were undergone detailed clinical examination, to rule out for other possible causes like conformational abnormality of stifle and exploitation of animal at work. About 2/3 of the cases were shows unilateral upward fixation of patella. It is attributed by progression of clinical signs from one to another limb rather sudden bilateral.
Although standing patellar desmotomy shows good surgical outcome as bringing normal activity of animal, mild swelling and bleeding noticed in some animals. But there is no known complications were noticed. In conclusion standing patellar desmotomy would be better surgical technique in the field. Pregnant animals have less risk in this technique than lateral recumbency (unpublished data). So skill development program with cadavers and training courses for field veterinarians may bring decreased course of illness.

Table 1 Clinical Parameters of Luxation of Patella in Cows

\begin{tabular}{|c|c|c|c|c|c|c|c|c|}
\hline S. No & Breed & Sex & Age & $\begin{array}{l}\text { Status of } \\
\text { animal }\end{array}$ & $\begin{array}{l}\text { Duration } \\
\text { of illness } \\
\text { (months) }\end{array}$ & $\begin{array}{c}\text { Severity } \\
\text { unilateral/bilateral }\end{array}$ & $\begin{array}{l}\text { Response of } \\
\text { previous } \\
\text { veterinarian }\end{array}$ & $\begin{array}{l}\text { Level of mineral } \\
\text { supplementation }\end{array}$ \\
\hline 1 & CBJ & $\mathrm{F}$ & 4 & Lactating & 3 & Unilateral & Postponed & Optimal \\
\hline 2 & CBJ & $\mathrm{F}$ & 4 & $\begin{array}{l}\text { Last trimester } \\
\text { of pregnancy }\end{array}$ & 6 & Unilateral & No response & Sub-optimal \\
\hline 3 & CBHF & $\mathrm{F}$ & 5 & $\begin{array}{l}\text { Last trimester } \\
\text { of pregnancy }\end{array}$ & 5 & Unilateral & Postponed & Sub-optimal \\
\hline 4 & CBJ & F & 5 & Lactating & 12 & Unilateral & Postponed & Sub-optimal \\
\hline 5 & CBHF & $\mathrm{F}$ & 6 & $\begin{array}{l}\text { Last trimester } \\
\text { of pregnancy }\end{array}$ & 12 & Unilateral & Postponed & Sub-optimal \\
\hline 6 & CBJ & F & 6 & $\begin{array}{l}\text { Last trimester } \\
\text { of pregnancy }\end{array}$ & 4 & Bilateral & No response & Sub-optimal \\
\hline 7 & CBJ & $\mathrm{F}$ & 6 & Lactating & 3 & Unilateral & Postponed & Sub-optimal \\
\hline 8 & $\mathrm{CBHF}$ & $\mathrm{F}$ & 5 & Lactating & 6 & Unilateral & No response & Sub-optimal \\
\hline 9 & $\mathrm{CBHF}$ & $\mathrm{F}$ & 5 & $\begin{array}{l}\text { Last trimester } \\
\text { of pregnancy }\end{array}$ & 3 & Unilateral & No response & Sub-optimal \\
\hline 10 & CBJ & F & 5 & Non-lactating & 1 & Unilateral & - & Sub-optimal \\
\hline 11 & CBJ & $\mathrm{F}$ & 4 & Lactating & 1 & Unilateral & - & Sub-optimal \\
\hline 12 & CBJ & $\mathrm{F}$ & 5 & Non-lactating & 3 & Unilateral & Postponed & Optimal \\
\hline 13 & CBJ & $\mathrm{F}$ & 5 & $\begin{array}{l}\text { Last trimester } \\
\text { of pregnancy }\end{array}$ & 6 & Unilateral & No response & Sub-optimal \\
\hline 14 & CBJ & $\mathrm{F}$ & 6 & Lactating & 12 & Unilateral & No response & Sub-optimal \\
\hline 15 & CBHF & $\mathrm{F}$ & 5 & Lactating & 8 & Bilateral & No response & Sub-optimal \\
\hline
\end{tabular}


Table.2 Surgical Parameters

\begin{tabular}{|c|c|c|c|c|c|c|}
\hline S. No & Breed & $\begin{array}{l}\text { Severance of } \\
\text { ligament }(\%) \\
\text { clinically }\end{array}$ & Swelling & Bleeding & $\begin{array}{c}\text { Other } \\
\text { complications if } \\
\text { any }\end{array}$ & $\begin{array}{c}\text { Outcome after } \\
\text { surgery }\end{array}$ \\
\hline 1 & $\mathrm{CBJ}$ & 100 & No & - & No & Good \\
\hline 2 & CBJ & 100 & No & - & No & Good \\
\hline 3 & $\mathrm{CBHF}$ & 100 & No & - & No & Good \\
\hline 4 & CBJ & 100 & No & - & No & Good \\
\hline 5 & $\mathrm{CBHF}$ & 100 & No & - & No & Good \\
\hline 6 & CBJ & 100 & Mild & Mild & No & Good \\
\hline 7 & CBJ & 100 & No & - & No & Good \\
\hline 8 & $\mathrm{CBHF}$ & 100 & No & - & No & Good \\
\hline 9 & $\mathrm{CBHF}$ & 100 & No & - & No & Good \\
\hline 10 & CBJ & 100 & No & - & No & Good \\
\hline 11 & $\mathrm{CBJ}$ & 100 & No & - & No & Good \\
\hline 12 & $\mathrm{CBJ}$ & 100 & No & - & No & Good \\
\hline 13 & CBJ & 100 & No & - & No & Good \\
\hline 14 & $\mathrm{CBJ}$ & 100 & Mild & Mild & No & Good \\
\hline 15 & $\mathrm{CBHF}$ & 100 & No & Mild & No & Good \\
\hline
\end{tabular}

CBJ-Cross Bred Jersey, CBHF- Cross Bred Holstein Friesian, F-Female

For prevention mineral supplementation and avoidance of other intrinsic factors by selection and management will be considered as future research goals for researchers.

\section{Acknowledgment}

The authors are very much thankful to the Tamilnadu Animal husbandry department and ICAR-IVRI provides technical and knowledge support for the conduction of research study.

Conflict of Interest: The authors declare that they have no conflict of interest

Ethical approval: As it's a clinical study no ethical permission could be invited

\section{References}

Chandrapuria, V.P., Bhadauria, P. and Jadoun, Y.S., 2012. Upward fixation of patella and its clinical management in large ruminants. Intas Polivet, 13(2), pp.259-261.

Da Silva, L.A.F., Fioravanti, M.C.S., Eurides, D., Atayde, I.B., Silva, C.A., Silva, O.C. and Trindade, B.R., 2004. Dorsal patellar fixation in cattle: desmotomy on lateral recumbency. Israel Journal of Veterinary Medicine, 59, pp.43-48.

Dhillon, K.S., Singh, J., Dhaliwal, B.B.S., Sharma, R. and Pannu, M.S., 2009. Patellar luxation in buffalo and its treatment. Buffalo Bull, 28, pp.168-169.

Hanson, R.R. and Peyton, L.C., 1987. Surgical correction of intermittent upward fixation of the patella in a Brahman cow. The Canadian Veterinary Journal, 28(10), p.675.

http://environmentclearance.nic.in/writereadd ata/District/surveyreport/14112018RFY JXR5QDSR.pdf (DSR), 2018

Naveen, M., Kumar, D.D., Shivaprakash, B.V., Usturge, S.M., Pawar, A. and 
Patil, N.A., 2013. Comparision of different methods of medial patellar desmotomy in bovines. Indian Journal of Veterinary Surgery, 34 (2), pp.94-96.

Paul R. Greeneough, 2015. Patellar Luxation in Cattle. In lameness in cattle. MSD Veterinary Manual

Salem District Disaster Management Plan (SDDM) 2018

Sherif, M.W.E.S., 2017. New Technique for
Medial Patellar Desmotomy in Cattle and Donkeys. Open Journal of Veterinary Medicine, 7(10), pp.144-150. Singh, A.K., Gangwar, A.K., Devi, K.S. and Singh, H.N., 2015. Studies on incidence and evaluation of the closed medial patellar desmotomy in lateral recumbency in bovines. Veterinary world, 8(2), p.221.

\section{How to cite this article:}

Kalaiselvan, E. and Desinguraja, D. 2020. Standing Patellar Desmotomy and its Outcome in Cows. Int.J.Curr.Microbiol.App.Sci. 9(07): 3546-3550.

doi: https://doi.org/10.20546/ijcmas.2020.907.414 